\title{
A digitalização de Acervos no IEB-USP: diretrizes para sua reestruturação
}

A Seção de Digitalização do IEB foi criada em 2004 e, desde então, tem investido na ampliação e na diversificação de seu parque de equipamentos, bem como na contratação de funcionários especializados. Iniciadas sob o signo da novidade, suas atividades foram marcadas pela produção em quantidade de imagens e pelo atendimento de demandas externas ao IEB, decorrentes de projetos e parcerias interinstitucionais, tornando-se referência dentro e fora da Universidade de São Paulo, no que tange à digitalização de documentos/obras em duas dimensões.

Motivada por discussões acerca da qualidade das imagens produzidas, a Seção caracteriza-se, atualmente, por uma orientação voltada à fidelidade dos representantes digitais ${ }^{1}$ dos documentos/obras. Beneficiada pelas atividades do Grupo de Pesquisa em Impressões Fotográficas (GPIF/CAP/ECA-USP) ${ }^{2}$, essa nova orientação se baseia em parâmetros técnicos que permitem aferir o andamento correto das etapas de captação, gerenciamento de cores e indexação dos arquivos gerados.

Nesse quadro, a digitalização passa a ser entendida também como uma ferramenta de proteção do acervo, visto que se pretende minimizar, por meio de consultas eletrônicas, o contato físico com os originais. Vale lembrar, ainda, que boas práticas de captação e a geração de matrizes digitais com qualidade e fidelidade, assim como o gerenciamento adequado dos arquivos eletrônicos, contribuem para evitar que se refaça a digitalização do material em curto prazo.

Por se tratar de uma atividade essencial e estratégica para a extroversão e preservação de seus acervos, a digitalização cria expectativas, gera demandas, fomenta a curiosidade e projeta a imagem de uma instituição. Para que funcione a contento, entretanto, essa atividade deve contemplar etapas distintas e complementares, algumas anteriores a captação das imagens:

- catalogação dos documentos/obras em sistema informatizado, permitindo a rápida recuperação de informações sobre os acervos;

1 De acordo com o documento do Conselho Nacional de Arquivos Recomendações para digitalização de documentos arquivisticos permanentes (abr. 2010, p. 4), o termo "representante digital" refere-se à representação, em formato digital, de um documento originalmente não digital.

2 Coordenado pelo Prof. João Luiz Musa (ECA-USP), o grupo conta com a participação de alunos da ECA e de funcionários do IEB. Desde 2011, desenvolve trabalhos na Seção a convite do Prof. Luiz Armando Bagolin (IEB-USP). 
- seleção dos itens a serem digitalizados, que deve se relacionar a demandas de pesquisa internas e externas - projetos temáticos, documentos mais requisitados -, à preservação - documentos/obras em situação de risco - e ao interesse público - documentos em domínio público, aptos à disponibilização via $w e b$;

- conservação preventiva: ações de higienização, consolidação de suportes e/ou intervenções de restauro;

- captura de imagens e seu tratamento, visando à geração de matrizes digitais para arquivamento e derivadas para usos diversos - difusão, publicações e consulta eletrônica;

- finalizando o processo, há de se fazer a gestão das imagens digitais por meio de um sistema informatizado e vinculado às bases de catalogação dos acervos ${ }^{3}$.

Esse trabalho vem sendo realizado pela equipe técnica do IEB com o apoio dos docentes da casa, mas o fluxo de trabalho tem encontrado limites na acanhada infraestrutura da Seção de Digitalização. O anseio de se ampliar essa estrutura motivou a reunião de técnicos, especialistas e docentes em torno de um projeto recentemente aprovado pela Pró-Reitoria de Pesquisa.

O projeto "Digitalização de acervos no Instituto de Estudos Brasileiros (IEB-USP): reestruturação, proteção e acesso" tem como coordenadores os Profs. Marcos Antonio de Moraes e Flávia Toni (vice) e contará com a assessoria técnica e científica da Profa. Telê Ancona Lopez. Os recursos obtidos permitirão não apenas a ampliação da infra-estrutura de captação como também investimentos na atualização de sistemas de gestão informatizada dos acervos e de seus representantes digitais.

A aplicação direta dos recursos terá como projeto-piloto uma seleção de documentos pertencentes ao Fundo Mário de Andrade. São manuscritos, impressos, correspondências, matérias extraídas de periódicos e fotografias, entre outros, de excepcional valor para o estudo da cultura brasileira. Vale ressaltar, no entanto que a digitalização de acervos no IEB não ficará restrita ao Fundo Mário de Andrade, uma vez que já

3 Esse trabalho é feito, atualmente, no Sistema de Gestão de Acervos do IEB (SGA), que foi desenvolvido internamente por pesquisadores envolvidos na catalogação dos acervos do Serviço de Arquivo, em parceria com o Laboratório de Informática da instituição. Em funcionamento desde 2010, esse software possui ferramentas para catalogação, controle de trânsito de documentos e gestão do Repositório Digital. 
existe uma demanda - diga-se, crescente - pela digitalização de outros fundos e coleções.

Além de proteger, as ações aqui descritas visam ainda difundir o rico acervo do Instituto, que é consultado por pesquisadores de diversas partes do Brasil e do exterior. Apesar das restrições impostas pelos direitos autorais, a facilidade de acesso promovida pela digitalização já tem demonstrado seus frutos, pois não são poucas as ocasiões em que imagens digitais de documentos em domínio público - ou mesmo passíveis de proteção, sob autorização - são enviadas eletronicamente aos pesquisadores de outros estados ou países. Assim, qualificada, a digitalização de acervos no Instituto de Estudos Brasileiros passa a refletir a excelência desse centro multidisciplinar de estudos sobre a cultura brasileira, agora também em meio digital.

José Hermes Martins Pereira.

Especialista em Pesquisa/Apoio de Museu do Instituto de Estudos Brasileiros. 
